\title{
MONITORING THE EFFECT OF MOTIVATION ON MASTERING KNOWLEDGE AND SKILLS IN DISTANCE LEARNING SYSTEMS
}

\author{
Boža D. Miljković ${ }^{a}$, Aleksandar V. Petojević ${ }^{b}$, Mališa R. Žižovićc \\ a University of Novi Sad, Faculty of Education Sombor, \\ Department of Informatics and Media, Republic of Serbia, \\ e-mail: bole@ravangrad.net \\ ORCID iD: (iohttp://orcid.org/0000-0002-2563-3694, \\ ${ }^{\mathrm{b}}$ University of Novi Sad, Faculty of Education Sombor, \\ Department of Mathematics, Republic of Serbia, \\ e-mail: apetoje@ptt.rs, \\ ORCID iD: (i) http://orcid.org/0000-0003-1491-165X \\ ${ }^{\mathrm{c}}$ Singidunum University Belgrade, Republic of Serbia, \\ e-mail: zizovic@gmail.com, \\ ORCID iD: (i)http://orcid.org/0000-0003-0789-8565
}

DOI: 10.5937/vojtehg64-10687

FIELD: Education, Technology Development

ARTICLE TYPE: Original Scientific Paper

ARTICLE LANGUAGE: English

\section{Summary:}

This paper describes how motivational processes affect students from the point of view of acquiring knowledge and skills, transfering them and using them in distance learning systems. Research in the social-cognitive framework illustrates the flexibility of the system and adequate adjustment of motivational patterns. A model of motivational processes, based on research, is presented as a function of learning objectives. The didactic-methodical approach to teaching was changed and adapted parallelly with monitoring the impact of the motivational factor on cognitive task performance and on students' responses, i.e. with the motivational factor influence on the success or failure of the cognitive outcome and the learning process quality. This work investigated the influence of specific knowledge areas and the interests of students on understanding professional or scientific lectures. The implications in practice and interventions done through the design of software of distance learning systems were aimed at correcting the educational process. Two forms of prior knowledge (expert knowledge and general thematic knowledge) were checked at the start as entrance tests and a preparatory course. After problem solving, a feedback analysis was carried out to determine the effects of 
prior professional knowledge, general thematic knowledge and interests on understanding and solving problems. The analysis of the results showed that for solving professional and technical tasks, prior knowledge of the domain, general thematic knowledge and interests were significant predictors of understanding and success.

Key words: motivation, learning, cognitive functions, emotions, prior knowledge, distance learning, affectivity.

\section{Introduction}

The educational process is a very complex and complicated process that involves the operation and interaction of many factors, the most significant ones being certainly course lecturers and participants, followed by other factors which in many ways can and should contribute to quality education. Among them are curricula, resources, forms of work, as well as factors related to personal characteristics of those who directly participate in the educational process, such as interests, openness, trust, etc., and, ofcourse, motivation. Motivation of participants in the educational process is an important precondition that can greatly contribute to a better realization of the educational process, so that better results are achieved as well as progress in learning. Therefore, motivation is one of the most important factors in the educational process because its presence can greatly facilitate and improve the teaching and learning process while its absence leads to devastating results.

Modern systems of education are increasingly based on newly developed techniques of learning, such as e-learning (EL), distance learning (DL), distributed knowledge centers, "cloud" systems, etc. In the future, it is also expected to see their further development and implementation as well as modern technological solutions for wider availability of education, specialization, teaching, training, etc. In these circumstances and this environment, methodological approaches to knowledge transfer must be adapted to the fact that there is no direct interaction, and that "on-line" lectures and consultations are replaced by specialized automated systems for learning, for example, Tutoring Systems (TS). Consequently, one of the leading challenges in the successful implementation of the concept of modern education is to recognize motivation, and how to keep up or increase the factor of motivation, and how to adjust the educational process to individual needs of course participants.

Adaptability, flexibility, understanding of individual characteristics and abilities of course participants are the characteristics that currently 
favor "live" teachers more than automated tutoring systems (TS). The process of education realized by the principles of intelligent tutoring systems (ITS) must follow and analyze cognitive experiences, emotional experiences and motivational experiences which determine a reaction to do "something" or manage the process of learning. The strength of this motivation often depends on how strongor important certain stimuli (emotions) are.

Emotional states have an important role in decision making, and problem solving, and communication, and negotiation, and motivation; therefore, recognition of emotionsis essential for the development of an intelligent interaction between people and computers. Positive emotions which arise during the educational process have a strong positive impact on learning for two reasons. First, positive emotions in general allow more creative and flexible thinking processes, increasing motivation so that course participants work harder and quitmore rarely. Another reason is that students consciously want to retain and possibly increase the intensity of the positive emotional state (which in this case comes from the education system) thus maintaining concentration and motivation for learning. In the case of externally generated positive emotions that are not directly related to the learning process and an automated system, student are not necessarily motivated or focused on keeping concentration to learn. So there is less motivation. The positive effect of these emotions is therefore less strong, and can even turn into a negative one if emotions are too intense (deconcentration). R. Kvaščev discusses the following features of an individual who is well motivated in the educational process:

- Development of powerful motivation to learn,

- Well integrated personality,

- Self-confidence, emotional stability, self-control, independence,

- Developed strong character and super ego,

- Developed risk taking and tolerance to frustration, and

- Mastering the methods and techniques of learning.

\section{Communication and Exchange of Information in the Process of Distance Learning}

The main challenge for teachers and learners alike is how to teach learners to learn. This is particularly evident in the case of application systems based on information and communications technologies (ICT) and DL technologies. Flexibility, personalization and different learning styles can be combined, and learning can be 
authentic, motivational and conceived as a part of a social process, creating an informal network of peer interactions. This leads to learning from each other (Punie et al, 2006). The process of learning, as much as it seems, is not isolated and limited to the world of ICT. An interaction with the environment is a constant. An additional reaction that developed through a new educational process is a humancomputer interaction.

Technical achievements in the development of ICT technologies enable learning materials to be chosen in desired forms for learning. Choosing an appropriate methodological and didactic approach to learning in a combination with determined individual differences in learning, detection of emotional intelligence and emotional states, learners can raise their performances in learning, which should lead to increased motivation and improved efficiency of the educational process (Grimley, Riding, 2009, pp.1-24).

For example, if proofing goes in a wrong direction, how to correct it, or how to implement these corrections, but not in the traditional manner (not to discard all effort), i.e. without negative effects such as demotivation, deconcentration, resentment, etc.? Future DL technologies must have solutions for the development of higher cognitive functions for mathematical or information theories, including concepts of motivation, emotions, instincts, intelligence, imagination and intuition. The intention is to activate the mechanisms of instinctive knowledge that provide a basic understanding of the world (Perlovsky, 2007).

How learners react to knowledge extended by DL technology and how they manifest reactions through the process can be found out only from feedback information. Reactions can be presented in various forms: a sound context, a visual context or through problem solving, tests, etc. Feedback (as a confirmation of understanding the message meaning) is sent to a system or to a person whose work is commented (eg. employee performance in a business environment). The communication process involves a two-way communication, which is the main advantage of modern tutors, so that the learning process is raised to a higher level, providing immediate feedback like reactions of learners on the course material, reactions through problem solving, but also a reaction on the system itself. Based on feedback and identification of differences between learners in the approach to solving problems and coping with the material, the system will adequately respond to the individual needs of the user through tutors, and correct or build on, for example, proofing so that it guides the user to the conclusions, in accordance with the prior knowledge and applying a coherent chain of logic. 


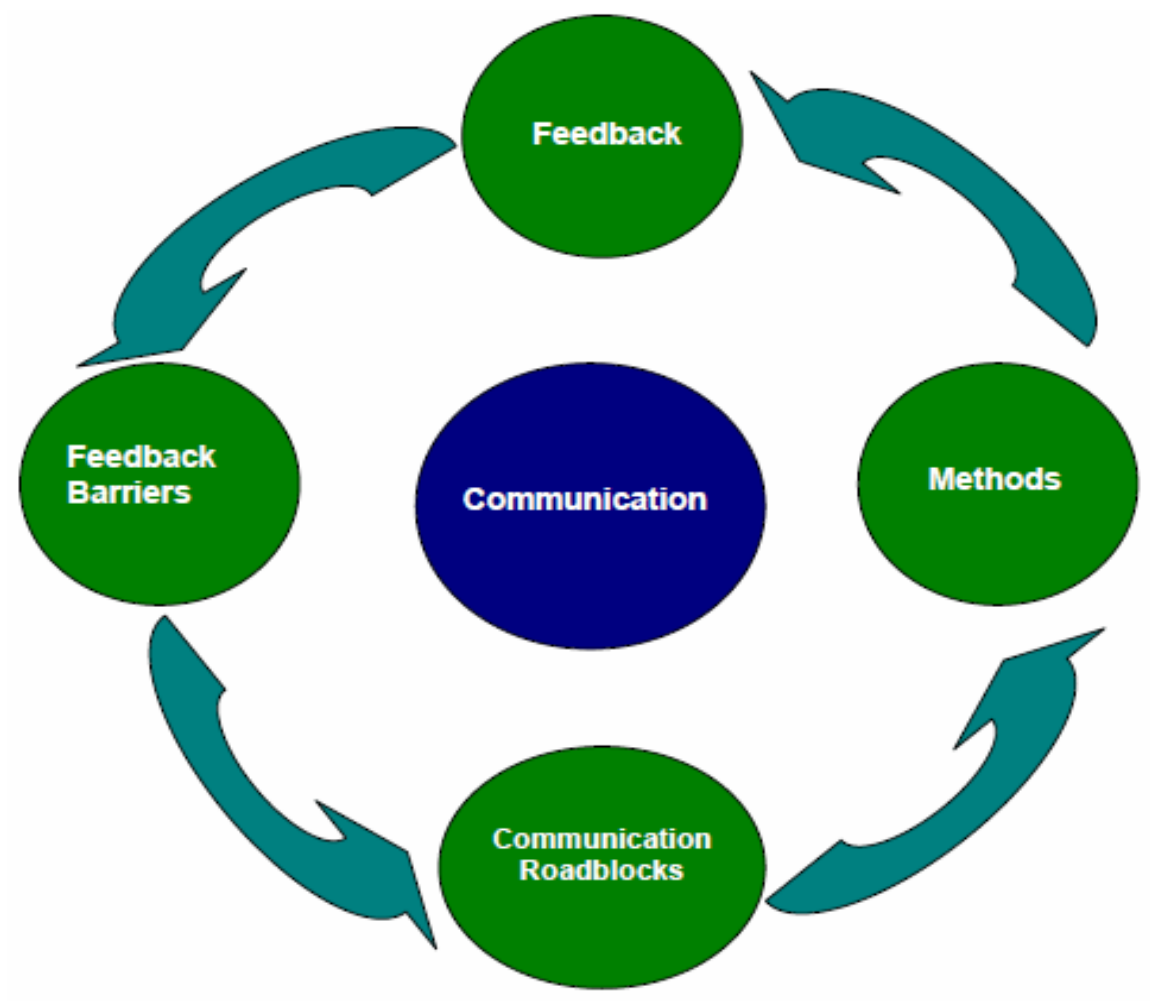

Figure 1 - Feedback cycle (Lawrence, Wiswell, 1995)

Puc. 1 - „Feedback“ цикл(Lawrence, Wiswell, 1995)

Slika 1 - „Feedback“ ciklus (Lawrence, Wiswell, 1995)

There are two types of feedback. The first is motivational feedback that stimulates the learner for something that has been done (praise). This reinforces good performance and increases the probability that it will happen again in the future. It must be given immediately after the completed task so that a person who is praised gains confidence and satisfaction of achievement. Another type of feedback is information feedback which advises the learner what to correct (improve). This points to a specific problem to be effectively solved. The best is to start with positive aspects that should encourage and motivate to continue the attempts to realize the educational process, notifyng the improvements. It must be stressed that too much negative feedback provokes defensiveness, and therefore may undermine the established flow of learning.

The analysis and discussion, in addition to providing examples of practical application of the results and solving methods, have a very important role in creating favorable conditions for the development of intrinsic motivation. 


\section{Motivation and Factors of Motivation}

Every learning is associated with prior knowledge and personal life experience. The dominant learning methods are: practical, working, or manual activities, expressive actions, laboratory work, social activities, field work, and observation of natural phenomena. Human behavior is purposeful and this purposefulness determines motivation in human behavior. Motivation to learn can be internal or external. Every objective that satisfies motivated behavior, and is located outside the body, can be called an external motive, regardless of whether it also meets some internal needs. M. Paleksić believes that an external stimulus in the education process should be an enhancing effect, one that encourages the promotion, development and enrichment of personality. Improving functions ensure not only the preservation and improvement of acquired competences, but also the acquisition of new types of skills. External motivation is the result of imposed actions, and therefore brings more relief than real pleasure brought by intrinsic motivation.

The most well-known definition of intrinsic motivation was givenby $\mathrm{E}$. L.Deci: Intrinsically motivated activities are those for which there is no apparent reward except the activity itself. People engage in activities for their own account, and not because these activities lead to an external reward. The very activity is the aim rather than the means.

The basic questions about intrinsic motivation are how to develop it with a help of a variety of educational, methodical and didactic resources, and how to encourage short-term motivation in order to develop long-term motivation.

In terms of the educational process, extrinsic motivation is:

- Focused on fulfilling the obligations in the educational process,

- Heavily influenced by external incentives or pressures,

- Leads to a surface approach to learning and to a fear of failure,

- The learning outcomes are not flexible and cannot be easily transformed into different contexts and fields of application.

The most common forms of extrinsic motivation are material rewards, grades, praise, awards, certificates, etc.

The intrinsic motivation:

- Reflects the personality,

- Arises from the interest for the field of study,

- Depends on the personal engagement in tasks that can be selected,

- Depends on one's own feelings of competence and selfconfidence,

- Leads to an in-depth approach to learning and understanding of concepts,

- The learning outcomes are flexible and can be easily transformed into different contexts and fields of application (Lungulov, 2010, pp.294-305). 
Modern research shows the importance of improving the impact of intrinsic motivation and intrinsic incentives, especially among students, sincethey are not properly developed although they considerably contribute to academic success and motivation for learning (Marić, Sakač, 2014, pp.63-79).

The learning process is accompanied not only by cognitive reactions but also by affective ones. From the viewpoint of gain in the educational process (the acquisition of knowledge and skills), affective reactions have a major impact on the motivational outcome (Lepper et al., 1993, pp.75-105). Previous studies mainly analyzed the influence of affective reactions on cognitive functions and processes. With the development of modern ITS, it became clear very quickly that the outcome of learning (among others) is in correlation with motivation, and that motivation is a function of emotional (affective) states. Keller's theory confirmed that motivation of the course participant plays a crucial role in the learning process. Therefore, it is now the central problem in ITS research and development to determine the tutorial strategy which can appropriately make a balance and compromise between cognitive, motivational and affective reactions of learners. Consequently, knowledge of the impact of the phenomenon of affective learning has led to the identification of a need to understand the phenomena of "bad timing" as a short time of disconcerting and the influence of affective states on cognitive and motivational characteristics in the learning process (Grafsgaard et al., 2013, pp.159-165).

Research has confirmed that motivational factors cannot fit into any template. Depending on feedback, ITS must first sort the purpose whether feedback has the purpose of increasing the overall efficiency of learning or solving a particular task. Positive "feedback" does not have the same effect (Boyeret al, 2008, pp.239-249). For example, a course participant without motivation due to low self-esteem can be encouraged to continue working with the DL system and the ITS system so that the system provides positive feedback (Tan, Biswas, 2006, pp.370-381). In contrast, some teaching tactics which require explicit security are best avoided for course participants who already have high motivation (Rebolledo-Mendez et al, 2006, pp.545-554). Studies have shown that students who had more control and corrections of affective states, experienced greater increase of self-confidence and achieved more in the learning process. With the ITC and the ITS through DL technology, teaching strategies can have a significant impact, not only on the success of pure cognitive learning outcomes, but also on an important motivational aspect such as self-confidence, which directly affects the environment of the educational process, and indirectly the achievement of learning process results. 
During modeling and testing modern ITS with adaptive characteristics, it was observed that the course participants willing to face the challenge of problem-solving tasks were considerably more involved in the learning process. Also, the ITS adaptivity, i.e. adapting ITS strategies to the course participant motivation, is a promising direction for improving dialogue with tutoring systems, which directly affects the efficiency of the educational process (Ezen-Can, Boyer, 2015, pp.105-114). An example of a model of such a system for monitoring and controlling the process of motivation and self-confidence is presented through the scheme of the clarifications of ambiguities, doubts, and prejudices theusual causes of uncertainty and motivation loss, Figure 2.

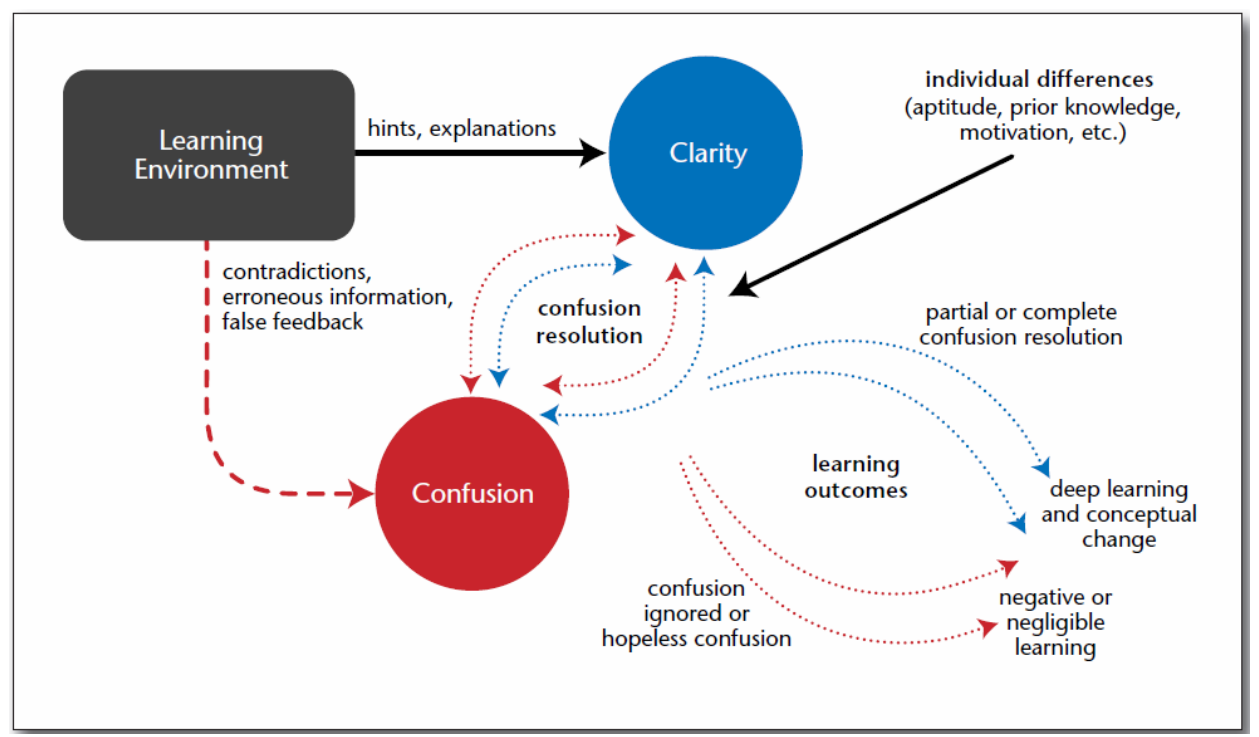

Figure 2 - Model of Confusion, Prejudice and Misunderstanding Induction and Resolution (Rus et al, 2013, pp.42-54)

Puc. 2 - Модель несоответствий, неточностей, сомнений, неясности, объяснений(Rus et al, 2013, pp.42-54)

Slika 2 - Model indukovanih nejasnoća, predrasuda i nedoumica, i razjašnjenje

(Rus et al, 2013, pp.42-54)

\section{Methodology of Research Work}

Four dimensions of motivation can influence the improvement of the educational process: control, curiosity, challenge and trust (Lepper et al., 1993, pp.75-105). For this reason, this paper is an attempt to explore the relationship between emotional, motivational, intellectual, and psychophysical characteristics of course participants and the interaction with the 
tutorial system at defined time or thematic sessions (there are dialogue tutors, texttutors, combined tutors, etc.). For the research study, a group of students attending the first year of study was divided into two subgroups. The first subgroup was with a lower motivational factor, and the second one was with a higher motivational factor.

The underlying idea is to analyze the recordings of exercises during the course and the consultations taken by an improvised automated center for distance learning with a simulated tutoring system. The environment was created as an interactive workshop through audio-vido sessions (Skype) and text conversations (chat). Cognitive processes were monitored through exercises where the agents, teaching staff of the course, led the sessions. Affective reactions and behavioral changes were monitored by agents simulated by psychological-pedagogical staff of the college.

For a more detailed analysis, the sessions were recorded audiovisually. The speech analysis software was used to monitor the emotional states of the course participants. Emotions in speech are reflected through the variations of voice characteristics at three levels: (1) prosodic, i.e. suprasegmental level through specific changes in frequency, intensity and duration, (2) segmental level (changes in the quality of articulation) and (3) intrasegmentnal level (global voice quality, acoustic correlates as a form of the glottal pulse and the distribution of its spectral energy, variations in amplitude (shimmer) and frequency (jitter)). In the man-machine dialogue in which machines analyze the emotional reactions of users, using the ESR (Emotional Speech Recognition) algorithm, the key words are recognised in their answers as well as the level of satisfaction (based on the identification and classification of emotions), the dialogue is led and the answers given so as to successfully accomplish the initiated communication.

Software for the analysis of video clips, i.e. analysis and monitoring of gestures, facial expressions, movements, body postures and looks, confirmed the detected emotional states, and more accurately described the emotional reactions already detected through the speech analysis.

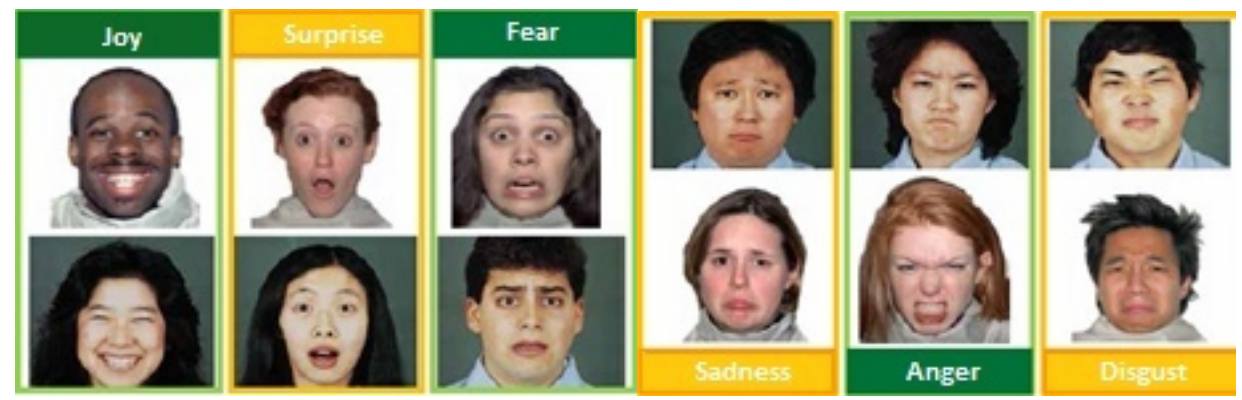

Figure 3 - The basic emotions (by Ekman)

Puc. 3 - Базовые эмоции (по Эксану)

Slika 3 - Osnovne emocije (po Ekmanu) 


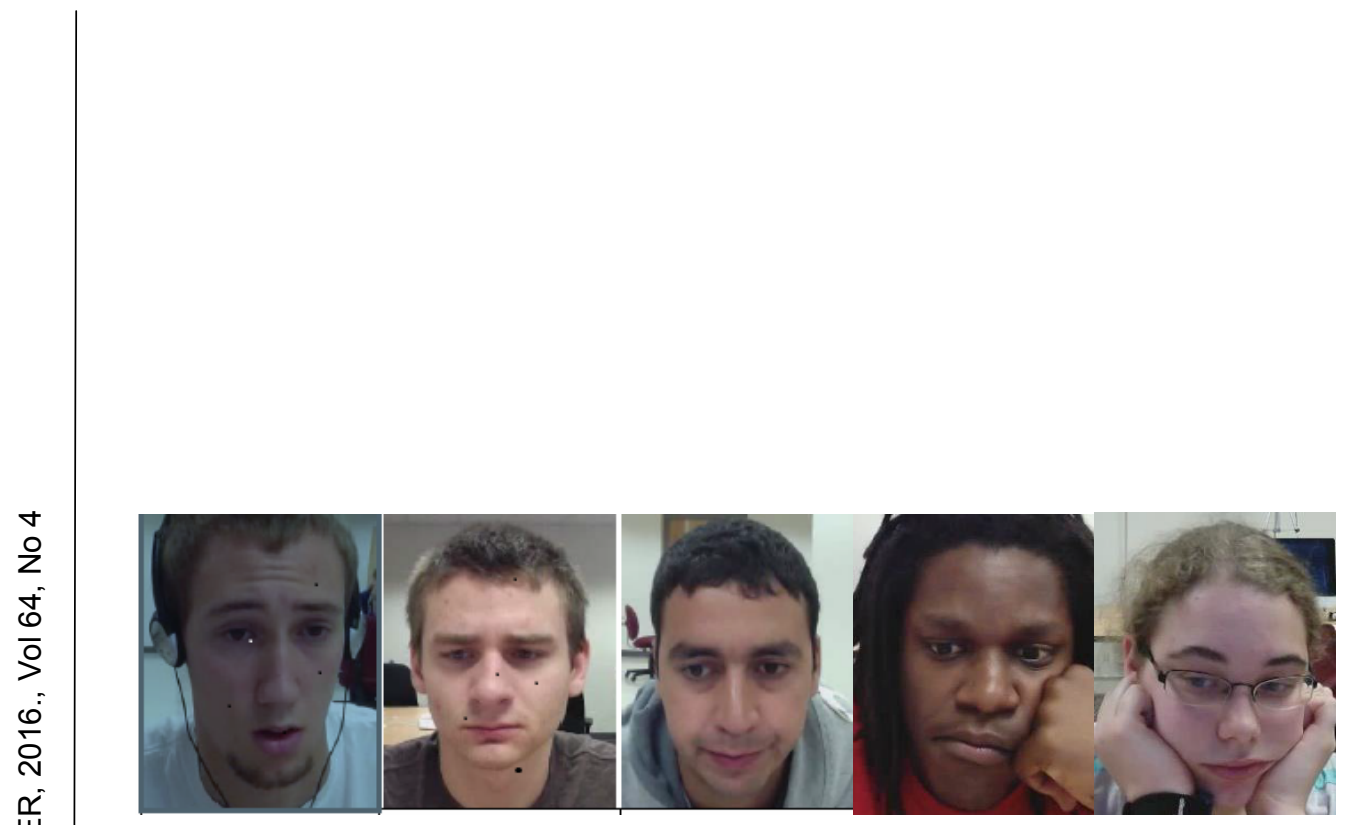

Figure 4 - Facial Expressions

Puc. 4 - Выражение эмоций на лице

Slika 4 - Facijalne ekspresije

\section{The formation of subgroups}

In order to understand and analyze the research results in a few steps, we determined the data which were to be viewed and which were essential in our analysis. Information technologies is the subject area in which testing was performed and the results analysed. The input data on the basis of which the students were divided into preliminary subgroups were: the entrance test results in the subject area, the compatibility of the curriculum of the previous level of education with the subject area and the results achieved in the previous level of education in the subject area.

Table 1 - Background Informationon the Course Participants-Prior Knowledge, Interest Таблица 1 - Данные о слушателях курса - предзнания, интересы Tabela 1 - Polazni podaci slušalaca kursa - predznanje, interesovanje

\begin{tabular}{|c|c|c|c|c|c|c|c|}
\hline No & Student & $\begin{array}{l}\text { Secondary } \\
\text { school- } \\
\text { orientation }\end{array}$ & $\begin{array}{l}\text { Secondary school - } \\
\text { professional subjects }\end{array}$ & $\begin{array}{c}\text { Compatibility } \\
\text { of curriculum } \\
(1-5)\end{array}$ & $\begin{array}{c}\text { The } \\
\text { mean } \\
\text { score in } \\
\text { pro- } \\
\text { fessional } \\
\text { subjects }\end{array}$ & $\begin{array}{c}\text { Success } \\
\text { in the } \\
\text { entrance } \\
\text { test } \\
(\max 30)\end{array}$ & Sum \\
\hline 1 & Student 1 & $\begin{array}{l}\text { Secondary } \\
\text { School of } \\
\text { Economics, } \\
\text { Kikinda - } \\
\text { Sales }\end{array}$ & $\begin{array}{l}\text { Computers \& IT x } \\
\text { 3Computer-Aided trade } \\
\text { E-business }\end{array}$ & 3.50 & 5.00 & 22.0 & 30.50 \\
\hline 2 & Student 2 & \begin{tabular}{c|} 
\\
Technical \\
School, \\
Sombor - el. \\
technicianof \\
computers
\end{tabular} & $\begin{array}{l}\text { Computers \& IT } \\
\text { IT in electrical } \\
\text { engineering } \\
\text { Computer } \\
\text { programming x } 4 \\
\text { Computers x } 2 \\
\text { Computer data } \\
\text { transmission } \\
\text { Digital electronics }\end{array}$ & 5.00 & 3.00 & 23.5 & 31.50 \\
\hline
\end{tabular}




\begin{tabular}{|c|c|c|c|c|c|c|c|}
\hline No & Student & $\begin{array}{l}\text { Secondary } \\
\text { school- } \\
\text { orientation }\end{array}$ & $\begin{array}{c}\text { Secondary school - } \\
\text { professional subjects }\end{array}$ & \begin{tabular}{|} 
Compatibility \\
of curriculum \\
$(1-5)$
\end{tabular} & \begin{tabular}{|c|} 
The \\
mean \\
score in \\
pro- \\
fessional \\
subjects
\end{tabular} & $\begin{array}{l}\text { Success } \\
\text { in the } \\
\text { entrance } \\
\text { test } \\
(\max 30)\end{array}$ & Sum \\
\hline 3 & Student 3 & \begin{tabular}{c|} 
Secondary \\
School of \\
Economics, \\
Kula - \\
Business \\
Adm. \\
\end{tabular} & Computers \& ITx 2 & 2.50 & 5.00 & 22.0 & 29.50 \\
\hline 4 & Student 4 & \begin{tabular}{|c|} 
Technical \\
School Kula- \\
Mech. tech. \\
for \\
computational \\
construction \\
\end{tabular} & $\begin{array}{l}\text { Computer programming } \\
\times 2 \text { Computer graphic } \\
\text { design Automation } \\
\text { and robotics }\end{array}$ & 4.00 & 4.00 & 21.5 & 29.50 \\
\hline 5 & Student 5 & \begin{tabular}{|c|} 
\\
Technical \\
School, \\
Sombor- \\
technician of \\
mechatronics \\
\end{tabular} & \begin{tabular}{|l|} 
Computers \& ITx 2 \\
Computer programming \\
Digital electronics \\
Microcontrollers \\
SCADA systems \\
Measure transducers \\
Programmable logical \\
controllers \\
Robotics \\
\end{tabular} & 5.00 & 4.00 & 23.0 & 32.00 \\
\hline 6 & Student 6 & \begin{tabular}{|c|}
$\begin{array}{c}\text { High School, } \\
\text { Apatin }\end{array}$ \\
\end{tabular} & Computers \& ITx 4 & 4.50 & 3.50 & 18.0 & 26.00 \\
\hline 7 & Student 7 & \begin{tabular}{|l|} 
Technical \\
School, \\
Sombor- \\
technician of \\
mechatronics
\end{tabular} & \begin{tabular}{|l|} 
Computers \& ITx 2 \\
Computer programming \\
Digital electronics \\
Microcontrollers \\
SCADA systems \\
Measure transducers \\
Programmable logical \\
controllers Robotics
\end{tabular} & 5.00 & 3.00 & 21.0 & 29.00 \\
\hline 8 & Student 8 & \begin{tabular}{|c|} 
Secondary \\
vocational \\
school, \\
Vrbas - \\
Environment \\
al protection \\
technician \\
\end{tabular} & $\begin{array}{l}\text { Computers \& ITx } 2 \\
\text { Automated data } \\
\text { processing }\end{array}$ & 2.50 & 5.00 & 15.5 & 23.00 \\
\hline 9 & Student 9 & $\begin{array}{l}\text { Secondary } \\
\text { Vocational } \\
\text { School, } \\
\text { Crvenka - } \\
\text { Food } \\
\text { technician }\end{array}$ & Computers \& ITx 2 & 2.00 & 2.00 & 22.0 & 26.00 \\
\hline 10 & Student 10 & $\begin{array}{l}\text { Politechnical } \\
\text { Secondary } \\
\text { School, } \\
\text { Subotica - } \\
\text { printing } \\
\text { technician }\end{array}$ & \begin{tabular}{|l|} 
Computers \& ITx 3 \\
Basics of graphic techn. \\
$\times 2$ \\
Graphic design and \\
letter design
\end{tabular} & 3.00 & 2.75 & 20.0 & 25.75 \\
\hline
\end{tabular}




\begin{tabular}{|c|c|c|c|c|c|c|c|}
\hline No & Student & $\begin{array}{l}\text { Secondary } \\
\text { school- } \\
\text { orientation }\end{array}$ & $\begin{array}{l}\text { Secondary school - } \\
\text { professional subjects }\end{array}$ & $\begin{array}{c}\text { Compatibility } \\
\text { of curriculum } \\
(1-5)\end{array}$ & $\begin{array}{c}\text { The } \\
\text { mean } \\
\text { score in } \\
\text { pro- } \\
\text { fessional } \\
\text { subjects }\end{array}$ & $\begin{array}{c}\text { Success } \\
\text { in the } \\
\text { entrance } \\
\text { test } \\
(\max 30)\end{array}$ & Sum \\
\hline 11 & Student 11 & \begin{tabular}{|c|} 
Medical \\
Secondary \\
School \\
Sombor - \\
physiotherap \\
ist \\
\end{tabular} & Computers \& IT & 2.00 & 3.00 & 16.0 & 21.00 \\
\hline 12 & Student 12 & $\begin{array}{c}\text { Secondary } \\
\text { School of } \\
\text { Economics } \\
\text { Odzaci- } \\
\text { Business } \\
\text { technician }\end{array}$ & $\begin{array}{l}\text { Computers \& IT } \\
\text { Business IT }\end{array}$ & 2.50 & 3.50 & 12.5 & 18.50 \\
\hline 13 & Student 13 & $\begin{array}{l}\text { Agricultural } \\
\text { school, } \\
\text { Futog- } \\
\text { veterinary } \\
\text { technician }\end{array}$ & Computers \& IT & 2.00 & 4.00 & 13.0 & 19.00 \\
\hline 14 & Student 14 & $\begin{array}{l}\text { Technical } \\
\text { School } \\
\text { Sombor- } \\
\text { Computer } \\
\text { control } \\
\text { systems }\end{array}$ & $\begin{array}{l}\text { Computers \& IT } \\
\text { Computer graphics } \\
\text { CAM technology } \\
\text { CAM programming } \times 2 \\
\text { Design of tech. systems } \\
\times 2\end{array}$ & 4.50 & 3.18 & 24.6 & 32.28 \\
\hline 15 & Student 15 & \begin{tabular}{|l|} 
Technical \\
School \\
Odzaci- \\
Environment \\
al protection \\
technician \\
\end{tabular} & $\begin{array}{l}\text { Computers \& IT } \\
\text { Automated data } \\
\text { processing }\end{array}$ & 2.50 & 3.50 & 21.6 & 27.60 \\
\hline 16 & Student 16 & $\begin{array}{c}\text { Secondary } \\
\text { Vocational } \\
\text { School St } \\
\text { Sava, } \\
\text { Sombor- } \\
\text { Environment } \\
\text { al protection } \\
\text { technician } \\
\end{array}$ & $\begin{array}{l}\text { Computers \& IT } \\
\text { Automated data } \\
\text { processing }\end{array}$ & 2.50 & 3.50 & 14.4 & 20.40 \\
\hline 17 & Student 17 & $\begin{array}{c}\text { High School } \\
\text { Sombor- } \\
\text { humanities }\end{array}$ & Computers \& ITx 4 & 4.50 & 3.00 & 18.0 & 25.50 \\
\hline 18 & Student 18 & $\begin{array}{l}\text { Technical } \\
\text { School } \\
\text { Sombor- } \\
\text { Computer } \\
\text { control } \\
\text { systems }\end{array}$ & $\begin{array}{l}\text { Computers \& IT } \\
\text { Computer graphics } \\
\text { CAM technology CAM } \\
\text { programming } \times 2 \text { Design } \\
\text { of tech. systems } \times 2\end{array}$ & 4.50 & 2.57 & 12.6 & 19.67 \\
\hline 19 & Student 19 & $\begin{array}{l}\text { Secondary } \\
\text { School of } \\
\text { Economics } \\
\text { Kula - } \\
\text { Business } \\
\text { technician } \\
\end{array}$ & $\begin{array}{l}\text { Computers \& IT Business } \\
\text { correspondencex } 2 \\
\text { Business IT x } 2\end{array}$ & 3.50 & 5.00 & 20.0 & 28.50 \\
\hline
\end{tabular}


The following data and activities were analyzed:

- inputs

- boundaries

- entropy

- state of cognitive balance

- feedback mechanism

- adaptation mechanism

- development path, and

- gradual finalization.

The candidates with fewer than 20 input points and with more than 35 input points (shadowed in Table 1) were not taken into consideration, in accordance with the previously mentioned "Tan \& Biswas" and "Rebolledo-Mendez, Boulay \& Luckin" research works. In the preliminary activities, before the start of the course, professional orientation (aptitude) and learning styles were tested. Subgroups of students who had more or fewer points than the arithmetic mean (27.5 points) were formed. The first subgroup consisted of the students with less motivation, i.e.:

- students with a smaller number of input points than the average (27.5),

- students for whom aptitude and competence tests do not point to be those who learn through research and whose learning leads to concrete and tangible results,

- students whose learning style is not logical.

Games, quizzes, and tests were used in the research for detecting competencies, skills, and enhance incentives to make it easier to assess the reactions in order to make a right decision on the selection of tutorials.

\section{Corrective Changes of Subgroups}

In mathematics, the problem solving strategy is analysed while in informatics the code is analysed. In the code analysis, the tutor can use either the cause-consequence model, i.e. queries and statements or just state whether it is accurate or not. The decision is made based on the information about the motivation and emotional state of the student. Table 2 and Table 3 give the template swhich show the problem solving flow as well as the statements of the student during the problem solving and their occurrence frequency.

In the communication (dialogue), there are queries, statements, declarations, etc., based on which the current state of the learning flow can be described (Greetings, prepared questions, affirmative question, direct question, information request, observation, correction, clear feedback, unclear feedback, explanation, other, Yes-No answer, answer, positive feedback, clarifications). 
Table 2 - Students' dalogues, their features, sample statements and frequency of their occurrence

Таблица 2 - Диалог слушателей курса, характеристики, выражения лица и частотность их появления

Tabela 2 - Dijalog slušalaca kursa, karakteristike, uzorak iskaza i frekvencije njihovih pojava

\begin{tabular}{|l|l|c|}
\hline \multicolumn{1}{|c|}{ Dijalogue } & \multicolumn{1}{c|}{ Example } & Distr. (\%) \\
\hline Answer & $\begin{array}{l}\text { I am satisfied, but there is a lot of work at } \\
\text { home }\end{array}$ & 43.28 \\
\hline Statement & Personally, to me it is very interesting & 20.46 \\
\hline Confirmation & Ok. & 20.20 \\
\hline Query & How do I fix mistakes and fails? & 14.16 \\
\hline Clarification & LiveChat messages & 0.90 \\
\hline The request for the feedback & Is it clearer? & 0.50 \\
\hline Other & I.e. laugh & 0.50 \\
\hline
\end{tabular}

Table 3 - Excerpts from the corpus of dialogues with the tag: characteristics of communication

Таблица 3 - Выборка из корпуса диалогов с обозначенными характеристиками коммуникации

Tabela 3 - Izvod iz korpusa dijaloga sa oznakom karakteristike komunikacije

\begin{tabular}{|c|c|c|}
\hline \multicolumn{3}{|c|}{ The Student made the coded program } \\
\hline \multicolumn{3}{|c|}{ He received an error message after compiling the program } \\
\hline \multicolumn{3}{|c|}{ Recognizable gesture } \\
\hline Student & What should I change first & Query \\
\hline Tutor & Try here & Statement \\
\hline \multicolumn{3}{|c|}{ The Student changed the definition of a library } \\
\hline \multicolumn{3}{|c|}{ After compiling the program again he received an error message } \\
\hline Tutor & Similar mistake & Statement \\
\hline Tutor & Go back and add a mathematical library & Statement \\
\hline \multicolumn{3}{|c|}{ The Student changed the code } \\
\hline \multicolumn{3}{|c|}{ Compiling executed successfully } \\
\hline Student & Is it a good order & Query \\
\hline Tutor & Not consistently & Statement \\
\hline Student & The name of the variable is & Statement \\
\hline \multicolumn{3}{|c|}{ The Student changed the code } \\
\hline \multicolumn{3}{|c|}{ The Student ran the program successfully } \\
\hline Tutor & This is excellent & Positive feedback \\
\hline Tutor & A couple of tasks are ahead of us & Statement \\
\hline \multicolumn{3}{|c|}{ A distinctive facial expression } \\
\hline Student & This is very interesting & Statement \\
\hline Tutor & $\begin{array}{c}\text { Try not to repeat the same mistakes in future } \\
\text { tasks }\end{array}$ & Statement \\
\hline \multicolumn{3}{|c|}{ A new screen and a task } \\
\hline & A recognizable gesture & \\
\hline
\end{tabular}




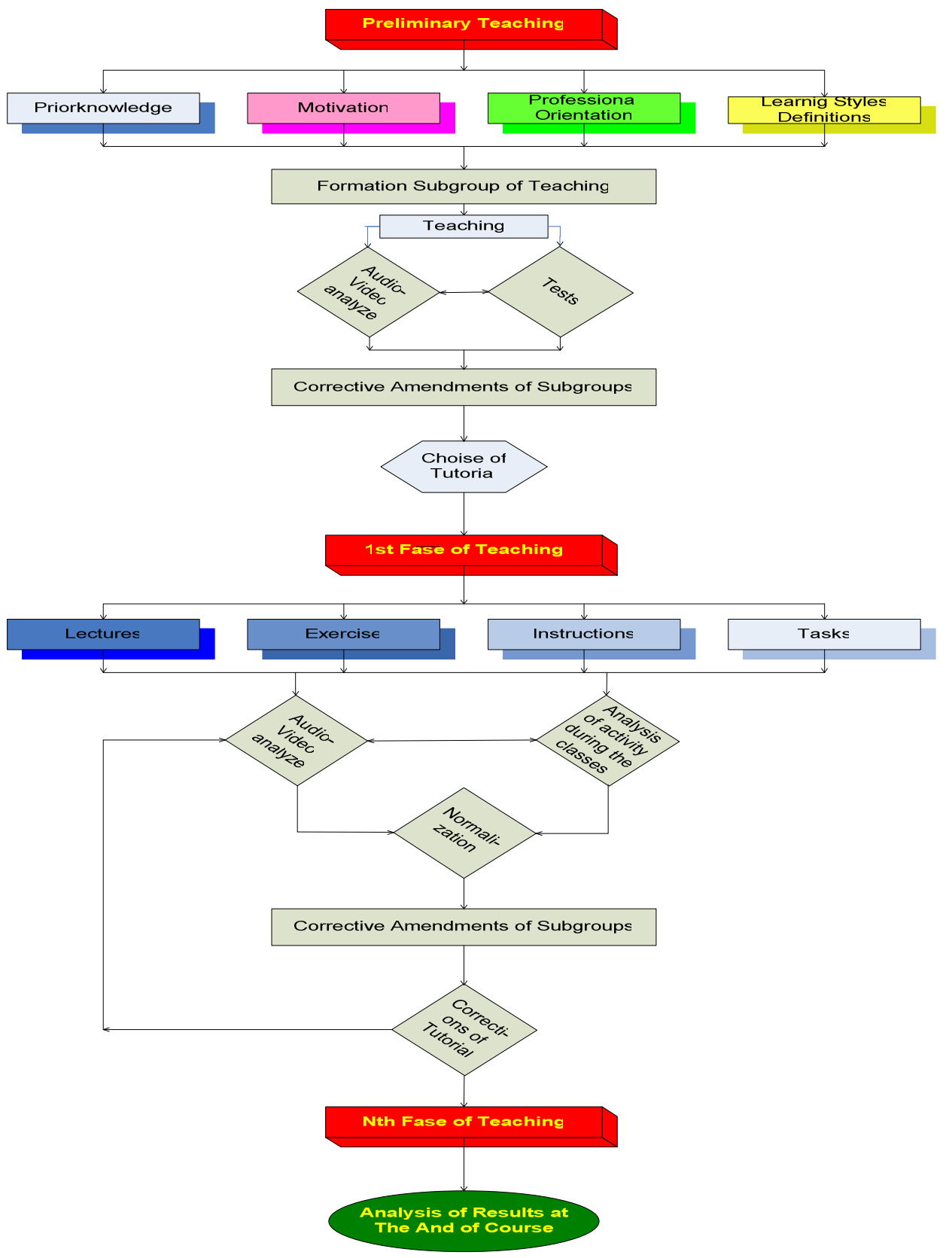

Figure 5 - Flowchart (SDL Diagram) of Forming Subgroups and Choice of Learning Environment, ITS

Puc. 5 - Процесс формирования подгруппы и выбор условий обучения, ITS Slika 5 - Tok procesa formiranja podgrupa i izbira okruženja učenja, ITS 
In our research, we were oriented to determine the data dominant in determining the ITS modules. The aim is to define an ITS module (determined by its basic characteristics, dynamics, type, and style of presentation) as early as possible (preferably at the start of the realization of the course - at the first class), and to implement individual corrections during the course on the assigned basic ITS model. In this way, we try to avoid changing a tutor model, which is often compared to the effect of changing a live lecturer, resulting in demotivation, fear, or insecurity.

So, all the reactions in characteristic situations are monitored, i.e. at which levels the characteristic reactions appear (type of emotions, intensity, rationality, motivation, etc.), and based on this information micro adjustments are carried out in the ITS module and the student subgroups, in accordance with the observed responses. Then the style and methods of work with individual subgroups are defined.

Further classifications are carried out based on the responses to tasks that come as "feedback", the reactions to erroneously solved tasks, the reactions to the advice that leads to the solution, and finally the reactions to the task when successfully solved. The aim is to analyze and review (based on feedback) which features should be implemented into tutorial learning systems, and to determine the standard deviation of the parameters of creating groups for which the system could successfully operate independently.

\section{Creating Alternative Goals}

The database of emotional algorithms and states is continuously upgraded and updated with models of behaviour and events for certain scenarios. The analysis of patterns for motivational groups in terms of timelines of events, types and intensities of students' emotional states and on the basis of the achieved results and goals, provides the system with the information about the events, i.e. which emotional change preceded the successful completion of a task. Also, if a student achieves targets $B$ and $C$ in time of communication ( $t$ ), but fails in achieving target $A$, the system must compare the type and intensity of emotions which were present at that moment, so that it can create an algorithm of a successful scenario, as an alternative to failure. The goal of the system is not only the successful completion of the task at any cost, but also maintaining a fair duration and mode of communication. In the knowledge base, the system must contain phase algorithms as well. If the goal is hardly feasible, interphases are sought. Those interphases will ensure the successful implementation of training programs, i.e. through realizing targets $B$ and $C$ in a certain period of time, it is expected that target $A$ will also be realized. 
In our research, this represents a so-called normalization, a variation of the educational process regarding emotional states and achieved results, i.e. success (if the goal Ais unattainable, to redirect the flow of learning tothe goal $B$ and create an alternative, i.e. the goal $\mathrm{C}$, with the possibility of eventually achieving the goal $A$ ).

\section{Research}

Monitoring and analyzing multimodal affective expressions enable monitoring of verbal and nonverbal behavior. These analyses have given us a potential to detect more early affective consequences regarding the detected learning performances (activity, frustrations and meticulous learning) and affective outcomes in the context of tutoring. In terms of initial information, the same affective expressions can have different causes by depending on the context of tutoring.

The students were monitored during the sessions, by monitoring their engagement and effectiveness in solving problems, Table 4. In addition, all sessions initiated by students themselves were recorded (their number, length, quality, time frame, during the classes separately and the whole semester as well.

Table $4-$ The records of sessions and activities by subject areas

Таблица 4 - Учет сессий и деятельности по образовательным областям Tabela 4 - Evidencija sesija i aktivnosti po nastavnim oblastima

\begin{tabular}{|c|c|c|c|c|c|c|c|}
\hline No & Student & $\begin{array}{c}\text { Learning } \\
\text { the } \\
\text { subject } \\
\text { material }\end{array}$ & $\begin{array}{c}\text { Consultations } \\
\text { (frequency) }\end{array}$ & Progress & $\begin{array}{c}\text { Emotional } \\
\text { changes }\end{array}$ & $\begin{array}{c}\text { No } \\
\text { sessions } \\
\text { by } \\
\text { subject } \\
\text { area }\end{array}$ & $\begin{array}{c}\text { Change in } \\
\text { methodology } \\
\text { during the } \\
\text { session }\end{array}$ \\
\hline 1 & $\begin{array}{c}\text { Student } \\
1\end{array}$ & Partly & NO & Poor & $\begin{array}{c}\text { Before the } \\
\text { test }\end{array}$ & 0 & NO \\
\hline 2 & $\begin{array}{c}\text { Student } \\
2\end{array}$ & YES & $\begin{array}{c}\text { YES-before } \\
\text { the test }\end{array}$ & Independent & $\begin{array}{l}\text { Before } \\
\text { exercise } \\
\text { classes }\end{array}$ & 1 & NO \\
\hline 3 & $\begin{array}{c}\text { Student } \\
3\end{array}$ & YES & YES & $\begin{array}{c}\text { By } \\
\text { consultation }\end{array}$ & \begin{tabular}{|c|} 
At the \\
occurrence \\
of the \\
problem
\end{tabular} & 5 & $2 x$ - efficiently \\
\hline 4 & \begin{tabular}{|c|} 
Student \\
4
\end{tabular} & YES & YES & $\begin{array}{c}\text { By } \\
\text { consultation }\end{array}$ & $\begin{array}{c}\text { For each } \\
\text { homework }\end{array}$ & 7 & $3 x$ - efficiently \\
\hline 5 & $\begin{array}{c}\text { Student } \\
5\end{array}$ & Partly & $\begin{array}{c}\text { YES-before } \\
\text { the test }\end{array}$ & Unsatisfactory & \begin{tabular}{|c|} 
Before \\
exercise \\
classes
\end{tabular} & 1 & NO \\
\hline 6 & $\begin{array}{c}\text { Student } \\
6\end{array}$ & Partly & DA & $\begin{array}{c}\text { By } \\
\text { consultation }\end{array}$ & \begin{tabular}{|c|} 
At the \\
occurrence \\
of the \\
problem \\
\end{tabular} & 5 & $\begin{array}{l}3 x \text { - partially } \\
\text { successful }\end{array}$ \\
\hline
\end{tabular}




\begin{tabular}{|c|c|c|c|c|c|c|c|}
\hline No & Student & $\begin{array}{c}\text { Learning } \\
\text { the } \\
\text { subject } \\
\text { material }\end{array}$ & $\begin{array}{l}\text { Consultations } \\
\text { (frequency) }\end{array}$ & Progress & $\begin{array}{c}\text { Emotional } \\
\text { changes }\end{array}$ & $\begin{array}{c}\text { No } \\
\text { sessions } \\
\text { by } \\
\text { subject } \\
\text { area } \\
\end{array}$ & $\begin{array}{c}\text { Change in } \\
\text { methodology } \\
\text { during the } \\
\text { session }\end{array}$ \\
\hline 7 & $\begin{array}{c}\text { Student } \\
7\end{array}$ & Partly & $\begin{array}{l}\text { YES-before } \\
\text { the test }\end{array}$ & No progress & $\begin{array}{l}\text { Before } \\
\text { exercise } \\
\text { classes }\end{array}$ & 1 & NO \\
\hline 8 & \begin{tabular}{|} 
Student \\
8
\end{tabular} & YES & YES & $\begin{array}{c}\text { By } \\
\text { consultation }\end{array}$ & $\begin{array}{c}\text { For each } \\
\text { homework }\end{array}$ & 5 & $\begin{array}{l}4 x \text { - partially } \\
\text { successful }\end{array}$ \\
\hline 9 & $\begin{array}{c}\text { Student } \\
9\end{array}$ & Partly & YES & $\begin{array}{c}\text { By } \\
\text { consultation }\end{array}$ & \begin{tabular}{|c|} 
At the \\
occurrence \\
of the \\
problem
\end{tabular} & 5 & $\begin{array}{l}3 x-\text { partially } \\
\text { successful }\end{array}$ \\
\hline 10 & $\begin{array}{c}\text { Student } \\
10\end{array}$ & NO & NO & Poor & $\begin{array}{c}\text { Before the } \\
\text { test }\end{array}$ & 0 & NO \\
\hline 11 & $\begin{array}{c}\text { Student } \\
11\end{array}$ & NO & NO & No progress & NO & 0 & NO \\
\hline 12 & $\begin{array}{c}\text { Student } \\
12\end{array}$ & Partly & $\begin{array}{l}\text { YES - on } \\
\text { demand }\end{array}$ & Poor & $\begin{array}{c}\text { Before the } \\
\text { test }\end{array}$ & 2 & NO \\
\hline 13 & $\begin{array}{c}\text { Student } \\
13\end{array}$ & Partly & $\begin{array}{l}\text { YES-before } \\
\text { the test }\end{array}$ & Poor & $\begin{array}{c}\text { At the } \\
\text { occurrence } \\
\text { of the } \\
\text { problem }\end{array}$ & 1 & $\begin{array}{c}1 x- \\
\text { unsuccessful }\end{array}$ \\
\hline 14 & $\begin{array}{c}\text { Student } \\
14\end{array}$ & YES & $\begin{array}{l}\text { YES - on } \\
\text { demand }\end{array}$ & Independent & $\begin{array}{c}\text { At the } \\
\text { occurrence } \\
\text { of the } \\
\text { problem }\end{array}$ & 2 & NO \\
\hline 15 & $\begin{array}{c}\text { Student } \\
15\end{array}$ & NO & NO & No progress & NO & 0 & NO \\
\hline 16 & \begin{tabular}{|l} 
Student \\
16
\end{tabular} & NO & NO & No progress & NO & 0 & NO \\
\hline 17 & $\begin{array}{c}\text { Student } \\
17\end{array}$ & NO & NO & No progress & NO & 0 & NO \\
\hline 18 & $\begin{array}{c}\text { Student } \\
18\end{array}$ & Partly & $\begin{array}{l}\text { YES-before } \\
\text { the test }\end{array}$ & No progress & $\begin{array}{c}\text { Before the } \\
\text { test }\end{array}$ & 1 & $\begin{array}{c}1 \mathrm{x}- \\
\text { unsuccessful }\end{array}$ \\
\hline 19 & $\begin{array}{c}\text { Student } \\
19\end{array}$ & YES & $\begin{array}{l}\text { YES - on } \\
\text { demand }\end{array}$ & Independent & NO & 4 & NO \\
\hline
\end{tabular}

During the sessions, there were corrective actions in order to adapt teaching (ITS simulation), in order to adjust to the level of prior knowledge, affective states, interests (whether a student joined the course because of intellectual curiosity or needs for a degree), style of learning in order to increase or at least preserve the initial level of motivation (starting enthusiasm). 
Students who actively participated in the sessions maintained or increased the starting level of motivation, with occasional oscillations overcome by corrective adjustments of the educational process in accordance with individual needs and current affective reactions. The success of these students, regardless of the subgroup (S3, S4, S6, S8, S9) was better (Be) or much better (MB). The exception is Student 19 (S19), with the initial assessment of the success of the implementation of the educational process very good (VG), whose emotional state during the course was closest to neutral. With a constant level of motivation, high quality level of prior knowledge, adequate professional orientation, and exceptional activities in regular classes, he achieved a much metter (MB) result.

Students who did not actively use the simulated DL system experienced a drop in motivation, which was detected at the periods of reporting (normally before the mid-term test or the exam). Affective states developed during the semester, the length, and the frequency of sessions (with exceptions) did not provide the time or the opportunity for corrective actions in order to return to the initial motivational level or at least to improve it a little. Those students (regardless of the subgroup), finished the course with bad (B) results, worse than expected (WE) results or in a few cases, with the expected results $(E)$ which were at the start of the course assessed as poor $(P)$.

Table 5 - One Look at the Results Achieved Through the Monitoring of Motivational Factors During the Course Realization by a Simulated ITS

Таблица 5 - Обзор результатов и наблюдение за изменениями мотивационного фактора в процессе проведения курса, путем моделирования ITS

Tabela 5 - Pogled na ostvarene rezultate uz praćenje promena motivacionog faktora tokomrealizacije kursa kroz simulirani ITS

\begin{tabular}{|c|c|c|c|c|c|c|c|c|c|c|c|c|c|c|c|c|c|c|}
\hline \multirow{3}{*}{$\begin{array}{l}\text { The Initial } \\
\text { Prerequi- } \\
\text { sites for } \\
\text { Success }\end{array}$} & & \multicolumn{9}{|c|}{ Subgroup 1} & \multicolumn{8}{|c|}{ Subgroup 2} \\
\hline & Student & S1 & S2 & S3 & S4 & S5 & S7 & S14 & S15 & S19 & S6 & S8 & s9 & S10 & S11 & S16 & S17 & S18 \\
\hline & $\begin{array}{c}\text { Expected } \\
\text { Success }\end{array}$ & VG & $E$ & $\mathrm{G}$ & VG & $E$ & $E$ & $E$ & $G$ & VG & G & $P$ & $\mathrm{P}$ & $P$ & $P$ & $\mathrm{P}$ & G & $P$ \\
\hline $\begin{array}{c}\text { Flow of } \\
\text { Motivation }\end{array}$ & $\begin{array}{c}\begin{array}{c}\text { ositive or } \\
\text { negative }\end{array} \\
\text {. }\end{array}$ & - & - & + & + & - & - & - & - & + & + & + & + & - & - & - & - & - \\
\hline $\begin{array}{c}\text { The } \\
\text { Achieved } \\
\text { Result }\end{array}$ & $\begin{array}{l}\text { Relation to } \\
\text { the Initial } \\
\text { Estimate }\end{array}$ & B & E & MB & $\mathrm{Be}$ & B & B & WE & WE & MB & $\mathrm{Be}$ & $\mathrm{Be}$ & $\mathrm{Be}$ & WE & E & B & $E$ & $E$ \\
\hline
\end{tabular}

LEGEND:

E-Excellent; VG-Very Good; G-Good; P-Poor

B-Bad; WE-Worse then Expected; E- Expected; Be-Better; MB-Much Better 


\section{Conclusion}

Negative emotions, poor skills, and inadequate environment of the educational process cause a drop in motivation. Without individualized corrective actions in the educational process, regaining motivation will not by itself lead to success; also, applying individualized corrective actions in the learning process without regaining motivation will have no effect.

In this study, it was observed that individual motivational expressions and actions during poblem solving increase the likelihood of raising selfefficacy and success in learning. The fact is, also, that this motivational tactics has a limited possibility to increase self-efficacy and gain in students who start the course with high quality and high initial self-efficacy.

The example of S19 student, a good course participant despite being a single case and not representative for the discussion, should be taken as a warning signal. Quality students with high abilities often think they do not need motivation or they do not appreciate the role of motivation, motivational sessions and tactics. In addition, it was noted during the sessions that the motivational components of curiosity and challenges hould be explored together with confidence and self-control in the context of the application of distance learningsystems.

Balancing and mainaining the environment of coupled cognitive and motivational functions has become a key issue in the theory of intelligent tutoring systems and systems of distance learning. Among other things, this work was guided by the idea to suggest how to determine the most efficient use of motivation in the context of feedback for students with problematic (affective) actions.

The research indicates that the application of ICT technologies and ITS in education in terms of adapting teaching strategies can have a significant impact not only on purely cognitive learning outcomes, such as the gain in knowledge and skills, but also on an important motivating aspect such as self-confidence.

The primary limitation of this study (similar to some previous research) comes from two drawbacks: $1^{\text {st }}$ the absence of control groups, and $2^{\text {nd }}$ an abundance of factors omitted or permitted to vary from a treatment to a new session appointment (Boyer et al, 2009, pp.111-136). These other factors (except those investigated) are probably responsible for the lack of a broader active participation and motivation of the course participants in the use of a simulated DL system. However, this work, among other things, reveals the breadth of the hypothesis of intelligent tutoring systems and their application in systems of distance learning, and may be the basis for future research and experiments. 


\section{References}

Boyer, K.E., Phillips, R., Wallis, D.M., Vouk, A.M., \& Lester, C.J. 2008. Balancing Cognitive and Motivational Scaffolding in Tutorial Dialogue. In: B. Woolf\& et al. Ur., ITS 2008, LNCS 5091. Berlin, Heidelberg: Springer-Verlag., pp.239-249.

Boyer, K.E., Phillips, R., Wallis, D.M., Vouk, A.M., \& Lester, C.J. 2009. Investigating the Role of Student Motivation in Computer Science Education through One-on-One Tutoring. Computer Science Education, iss. Author's preprint version, 19(2), pp.111-136.

Ezen-Can, A., \& Boyer, K.E. 2015. A Tutorial Dialogue System for Real-Time Evaluation of Unsupervised Dialogue Act Classifiers: Exploring System Outcomes. Artificial Intelligence in Education,, 9112 of the series Lecture Notes in Computer Science, pp.105-114. doi:10.1007/978-3-319-19773-9_11.

Grafsgaard, F.J., Wiggins, B.J., Boyer, K.E., Wiebe, N.E., \& Lester, C.J. 2013. Automatically Recognizing Facial Indicators of Frustration: A Learning-Centric Analysis. In: Humaine Association Conference on Affective Computing and Intelligent Interaction, Geneva, Switzerland. IEEE Computer Society Conference Publishing Services, CPS., pp.159-165. doi:10.1109/ACII.2013.33.

Grimley, M., \& Riding, R. 2009. Individual Differences and Web-Based Learning, Cognitive and emotional processes in web-based education: Integrating human factors and personalization. U C. Mourlas, N. Tsianos, \& P. Germanakos Ur. Pennsylvania, USA: IGI Global., pp.1-24. Chapter 1.

Lawrence, H.V., \& Wiswell, A.K. 1995. Feedback in a two-way street. Training \& Development, 49.

Lepper, M.R., Woolverton, M., Mumme, D.L., \& Gurtner, J. 1993. Motivational techniques of expert human tutors: Lessons for the design of computer-based tutors. $U$ S.P. Lajoie\& S.J. Derry Ur., Computers as Cognitive Tools. Hillsdale: Lawrence Erlbaum Associates, Inc.., pp.75-105.

Lungulov, B. 2010.Motivacija učenika u nastavi - pretpostavka uspeha u učenju. Pedagoška stvarnost, Univerzitet u Novom Sadu, Filozofski fakultet, 56(3-4), pp.294-305.

Marić, M.,\& Sakač, M., 2014, Individual and social factors related to students' academic achievement and motivation for learning. Suvremena Psihologija, 17(1), pp.63-79.

Perlovsky, L. 2007. Modeling Field Theory of Higher Cognitive Functions. Air Force Research Center.USA: Idea Group Inc.

Punie, Y., Cabrera, M., Bogdanowicz, M., Zinnbauer, D., \& Navajas, E. 2006.The Future of ICT and Learning in the Knowledge Society. In: Report on a Joint DG JRC-DG EAC Workshop held, 2005, Seville: European Commission - Joint Research Centre Institute for Prospective Technological Studies. EUR 22218EN (Technical Report No.EUR 22218 EN).

Rebolledo-Mendez, G., Boulay, B., \& Luckin, R. 2006. Motivating the learner: An empirical evaluation. In: Proceedings of the 8th International Conference on Intelligent Tutoring Systems, Jhongli, Taiwan, pp.545-554.

Rus, V., D'Mallo, S., Xiangen, H., \& Graesser, A.C. 2013. Recent Advances in Conversational Intelligent Tutoring Systems. Al Magazine, pp.42-54.

Tan, J., \& Biswas, G. 2006. The role of feedback in preparation for future learning: A case study in learning by teaching environments. In: Proceedings of the 8th International Conference on Intelligent Tutoring Systems, Jhongli, Taiwan, pp.370-381. 


\section{ВЛИЯНИЕ МОТИВАЦИИ НА ПРОЦЕССЫ ОВЛАДЕНИЯ ЗНАНИЯМИ, УМЕНИЯМИ И НАВЫКАМИ В СИСТЕМЕ ДИСТАНЦИОННОГО ОБРАЗОВАНИЯ}

Божа Д. Милькович ${ }^{a}$, Александр В. Петрович ${ }^{6}$, Малиша Р. Жижовичв

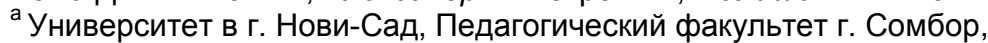
Кафедра информатики и медиатехнологий, г. Сомбор,

Республика Сербия

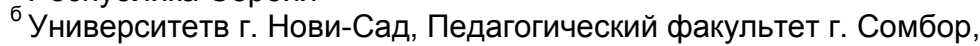
Кафедра математики, г. Сомбор, Республика Сербия

в Университет «Сингидунум», Кафедра информатики и математики, г. Белград, Республика Сербия

ОБЛАСТЬ: образование, технологическое развитие ВИД СТАТЬИ: оригинальная научная статья ЯЗЫК СТАТЬИ: английский

\section{Резюме:}

В данной статье описано, каким образом мотивационные процессы влияют на слушателей курса системы дистанционного образования, в т.ч. на восприятие знаний, овладение ими и на применение знаний, умений и навыков. Социально-когнитивные исследования свидетельствуют о высокой степени приспособленности системы и соответствии применяемых мотивационных моделей. Модель мотивационных процессов в исследовании представлена $c$ целью совершенствования дистанционной системы обучения. При наблюдении за влиянием мотивационных фракторов на выполнение когнитивных задач, и по выражениею реакций слушателей курса, можно определить какие мотивационные фракторы способствуют осуществлению положительных и отрицательных когнитивных результатов, в связи с чем, дидактические методы и приемы в процессе обучения периодически подвергались изменениям. Цель данной работы заключалась в исследовании влияния мотивационного фрактора на овладение знаниями и профессиональными навыками, а также в наблюдении за проявленным интересом слушателей курса $к$ научным лекциям. На основании выявления несоответствия мотивационных процессов с помощью дизайна программного обеспечения, разработанного для дистанционного образования, проводится корректирование условий и методов обучения. Сам процесс выявления основан на наблюдении роста знаний по сравнению с предварительными, так называемыми предзнаниями: 1. профессиональные предзнания и 2. общеобразовательные предзнания, проверенные вступительными тестами и на подготовительных курсах. В результате решения задач по данным вопросам проведен 
анализ влияния профрессиональных предзнаний, общеобразовательных знаний и заинтересованности учащихся на восприятие, понимание и решение задач и достижение результатов. Результаты проведенного анализа показали, что в успешном понимании и решении профрессионально-технических задач общеобразовательные предзнания и заинтересованность учащихся играют ключевую роль.

Ключевые слова: мотивация, обучение, когнитивные фрункции, эмоции, базовые знания, дистанционное образование, афффекты.

\section{PRAĆENJE UTICAJA MOTIVACIJE NA PROCESE APSOLVIRANJA} ZNANJA I VEŠTINA U SISTEMU UČENJA NA DALJINU

Boža D. Miljkovića ${ }^{\text {, Aleksandar V. Petojević }}{ }^{b}$, Mališa R. Žižovićc

a Univerzitet u Novom Sadu, Pedagoški fakultet Sombor,

Katedra informatike i medija, Sombor, Republika Srbija

${ }^{b}$ Univerzitet u Novom Sadu, Pedagoški fakultet Sombor,

Katedra za matematiku, Sombor, Republika Srbija

${ }^{\mathrm{c}}$ Univerzitet Singidunum, Katedra za informatiku i matematiku,

Beograd, Republika Srbija

OBLAST: obrazovanje, tehnološki razvoj

VRSTA ČLANKA: originalni naučni članak

JEZIK ČLANKA: engleski

\section{Sažetak:}

U radu je opisano kako procesi motivacije utiču na slušaoce kursa sa stanovišta apsolviranja znanja, te prenosa i korišćenja znanja i veština u sistemu učenja na daljinu. Istraživanja, u socijalno-kognitivnom okviru, ilustruje prilagodljivost sistema i adekvatno prilagođavanje motivacionih obrazaca. Model motivacionih procesa predstavljen je u funkciji ciljeva učenja slušalaca kursa. Praćenjem uticaja motivacionog faktora na izvršavanje kognitivnih zadatka, te kako se oblikuju reakcije slušalaca kursa, tj. kako motivacioni faktor utiče na uspeh ili neuspeh $i$ kvalitet kognitivnog učinka u procesu učenja, menjan je i prilagođavan metodičko-didaktički pristup nastavi. $U$ ovom radu istraživan je uticaj znanja iz uže stručne oblasti, ali i interesovanja slušalaca kursa za razumevanje stručnog ili naučnog izlaganja. Implikacije u praksi i intervencija, kroz dizajn softvera sistema učenja na daljinu, usmerene su na korekciju obrazovnog procesa na konstatovanu neprilagođenost motivacionih procesa u okruženju učenja ili stručnog osposobljavanja, prateći kroz istraživanje dva oblika predznanja: stručno predznanje i opšte tematsko predznanje, koja su proveravana ulaznim testovima predznanja, te kroz pripremnu nastavu. Nakon rešavanja problemskih zadataka izvršili smo povratnu analizu utvrđivanja efekata stručnog predzna- 
nja, opšteg tematskog znanja i interesovanja na razumevanje i rešavanje problemskih zadataka, te analizu ostvarenih rezultata. Za zadatke više stručno-tehničke orijentacije, predznanje iz domena opšte tematsko znanje i interes bili su značajni prediktori razumevanja i uspeha.

Ključne reči: motivacija, učenje, kognitivne funkcije, emocije, predznanje, učenje na daljinu, afekti.

Paper received on / Дата получения работы / Datum prijema članka: 09. 04. 2016.

Manuscript corrections submitted on / Дата получения исправленной версии работы / Datum dostavljanja ispravki rukopisa: 21. 06. 2016.

Paper accepted for publishing on / Дата окончательного согласования работы / Datum konačnog prihvatanja članka za objavljivanje: 23. 06. 2016.

(c) 2016 The Authors. Published by Vojnotehnički glasnik / Military Technical Courier (www.vtg.mod.gov.rs, втг.мо.упр.срб). This article is an open access article distributed under the terms and conditions of the Creative Commons Attribution license (http://creativecommons.org/licenses/by/3.0/rs/).

(c) 2016 Авторы. Опубликовано в "Военно-технический вестник / Vojnotehnički glasnik / Military Technical Courier" (www.vtg.mod.gov.rs, втг.мо.упр.срб). Данная статья в открытом доступе и распространяется в соответствии с лицензией "CreativeCommons" (http://creativecommons.org/licenses/by/3.0/rs/).

(c) 2016 Autori. Objavio Vojnotehnički glasnik / Military Technical Courier (www.vtg.mod.gov.rs, втг.мо.упр.срб). Ovo je članak otvorenog pristupa i distribuira se u skladu sa Creative Commons licencom (http://creativecommons.org/licenses/by/3.0/rs/). 